\section{Allergy to purified bovine, porcine, and human insulins}

We report a case of local and generalised allergy to highly purified insulins that persisted despite change to human insulin.

\section{Case report}

A 44 year old non-atopic man was diagnosed as being diabetic in 1978 and started insulin treatment in April 1981 with once daily Lentard (highly purified bovine and porcine insulin). Five days later he noticed local itchy weal and flare reactions lasting one to two hours. Insulin was stopped after six weeks.

In March 1982 once daily Actrapid and Monotard (highly purified porcine insulins) were introduced. After his second injection local reactions reappeared and persisted despite oral prednisolone. On 1 April 1982 he experienced generalised itching, sweating, vomiting, dizziness, and collapse three minutes after an injection. Previous injection sites became red, swollen, and indurated. He was hypotensive but not hypoglycaemic. Insulin was stopped. Thirst, polyuria, and ketonuria returned and twice daily Humulin S (recombinant human insulin) was started two days later as previous prick tests with human insulin had shown no reactions. Prick tests three days later showed immediate local reactions to all commercially available insulins

IgG insulin binding during illness

\begin{tabular}{lccc}
\hline \multirow{3}{*}{ Date } & \multicolumn{3}{c}{ IgG insulin binding $(\mu \mathrm{g} / 1)$} \\
\cline { 2 - 4 } & $\begin{array}{c}\text { Bovine } \\
\text { insulin }\end{array}$ & $\begin{array}{c}\text { Porcine } \\
\text { insulin }\end{array}$ & $\begin{array}{c}\text { Human } \\
\text { insulin }\end{array}$ \\
\hline 2 April & $9 \cdot 6$ & $11 \cdot 4$ & $2 \cdot 6$ \\
30 April & $40 \cdot 8$ & 17.9 & $8 \cdot 2$ \\
28 May & $34 \cdot 9$ & $14 \cdot 4$ & $8 \cdot 4$ \\
\hline
\end{tabular}

including: recombinant human insulin (Humulin S, Humulin I) (weal size at 10 minutes $1-3 \mathrm{~mm}$ ); semisynthetic human insulin (Actrapid human) and highly purified porcine insulins (sodium pork insulin (Eli Lilly), Actrapid, monotard) (weal sizes $4-6 \mathrm{~mm}$ ); and highly purified bovine insulins (Neusulin, Neuphane, Actrapid beef (Novo Laboratories) and histamine (weal sizes 6-9 mm). There was no reaction to any diluent, isopropyl alcohol, zinc sulphate, or control solutions. Prednisolone was stopped.

His condition improved and he gained weight, but local immediate and delayed reactions again became troublesome and in May he suffered a wheezing episode associated with redness and induration at previous injection sites shortly after an injection of Humulin S. Addition of dexamethasone $\mathbf{0 . 0 5} \mathrm{mg} /$ injection satisfactorily suppressed the reactions. Three months later the local reactions had disappeared and dexamethasone was reduced and stopped. He remained well.

Investigations-Full blood count was normal (eosinophils $3^{\%}$ of $8.9 \times$ $10^{9} / 1$ ) and total serum IgE concentrations on 30 April was $18 \mathrm{U} / \mathrm{ml}$ (Pharmacia PRIST method, normal $<120 \mathrm{U} / \mathrm{ml}$ ). Insulin specific IgE was exceptionally high at $26 \mathrm{U} / \mathrm{ml}^{1}{ }^{1}$ IgG insulin antibodies were measured as previously described. ${ }^{2}$ Before human insulin was started his serum showed appreciable binding for purified bovine and porcine insulins with little reactivity against human insulin (table). Samples taken after prick testing showed a pronounced rise in insulin antibody levels with a preferential binding to bovine insulin.

\section{Comment}

The cause of insulin allergy and nature of the antigen remain obscure. Our patient was not allergic to zinc or the insulin diluents and had never received protamine insulins. He received only purified insulins but mixtures of bovine and porcine insulins may have greater antigenicity than either alone. ${ }^{3}$ Although initially unreactive, he subsequently reacted to human insulin. Allergic reactions to purified insulins (and human insulin) have been observed but only after previous exposure to conventional insulins." Generalised reactions are uncommon and usually now seen only on reintroduction of insulin after a previous short course. ${ }^{3}$

The relation between circulating insulin antibodies and insulin allergy remains unclear. A proportion, but not all, of those receiving insulin develop insulin antibodies ${ }^{2}{ }^{3}$; few, however, show allergy or resistance. Patients with generalised insulin allergy have high concentrations of insulin specific $\operatorname{IgE}(1 \cdot 0-18 \cdot 4 \mathrm{U} / \mathrm{ml})$, which is independent of total $\mathrm{IgE}$ and insulin specific $\mathrm{IgG}^{1}$; such high concentrations have not been recorded in patients with local insulin allergy alone. The pronounced rise in our patient's IgG insulin antibodies with preferential binding to bovine insulin implies recent exposure to bovine insulin. He received no bovine insulin other than during skin testing. His allergy may thus have been exacerbated by the bovine insulin used for skin testing, which emphasises that skin testing is not without risk.

Although our patient showed hypersensitivity to human insulin, the reaction was less than that to other insulins. The use of human insulin, with or without low dose dexamethasone, may be useful in the management of insulin allergy.

We thank Dr D A Pyke and Dr P J Watkins for permission to report this case; Dr Karen Falholt (Novo Research Institute, Bagsvaerd, Denmark) for the determination of insulin specific IgE; and Wellcome Foundation Ltd, Novo Laboratories Ltd, and Eli Lilly \& Co for providing samples for skin testing and supplies of human insulin.

1 Falholt K. Determination of insulin specific IgE in serum of diabetic patients by solid-phase radioimmunoassay. Diabetologia $1982 ; 22: 254-7$.

${ }^{2}$ Reeves WG, Kelly U. Insulin antibodies induced by bovine insulin therapy. Clin Exp Immunol 1982;50:163-70.

${ }^{3}$ Kurtz AB, Nabarro JDN. Circulating insulin-binding antibodies. Diabetologia 1980;19:329-34.

- Leslie D. Generalised allergic reaction to monocomponent insulin. Br Med f 1977;ii :736-7.

(Accepted 25 April 1983)

Diabetic Clinic, King's College Hospital, London SE5 9RS

PHILIP G WILES, BSC, MRCP, research fellow

ROLAND GUY, MA, MRCP, registrar

Lister Hospital, Stevenage, Hertfordshire

SYLVIA M WATKINS, DM, FRCP, consultant physician

University Hospital, Nottingham

W G REEVES, BSC, FRCP, consultant immunologist and senior lecturer

Correspondence to: Dr Philip G Wiles.

\section{Cardiac arrest after crush injury}

The features of the crush syndrome were described during the second world war. ' Although severe crush injuries are uncommon in civilians, anecdotal reference has been made to sudden death after release from severe crushing. ${ }^{2}$ We report a case of cardiac arrest and successful resuscitation one hour after release from prolonged crushing and suggest that biochemical abnormalities may be a cause of sudden death after release from severe prolonged crushing.

\section{Case report}

A 47 year old man was crushed when three floors of a derelict tenement building collapsed. Extrication was slow because of the danger of further falls of masonry. He was trapped by a large mass of debris, and only the head, right arm, and shoulder were exposed. He was fully orientated, his pulse was 90 beats/min, and ventilation was adequate. Morphine was given via an intravenous infusion, according to the amount of pain experienced. Oxygen was given by face mask, and $500 \mathrm{ml}$ physiological saline and $500 \mathrm{ml}$ polygeline (Haemaccel) were given intravenously over four hours. He was released after eight hours. There were no obvious major injuries. Blood pressure was $90 \mathrm{~mm} \mathrm{Hg}$ systolic and pulse 100 beats/min. Further examination in the accident department showed two fractured ribs and compression marks on both legs; he had no other injuries. The foot pulses were easily palpable.

Arterial blood gas tensions just before cardiac arrest, which occurred one hour after release from crushing, were: $\mathrm{pH} 7 \cdot 15$, oxygen $15 \mathrm{kPa}(113 \mathrm{~mm} \mathrm{Hg})$, carbon dioxide $4.7 \mathrm{kPa}(35 \mathrm{~mm} \mathrm{Hg})$ and base excess $-17 \mathrm{mmol}(\mathrm{mEq}) / 1$. Resuscitation converted ventricular fibrillation to a supraventricular tachycardia with an adequate cardiac output, and the acidosis was treated with $300 \mathrm{mmol}(\mathrm{mEq})$ sodium bicarbonate intravenously. Blood was taken for estimation of electrolyte concentrations, and 15 minutes later he became asystolic. While resuscitation was in progress the electrolyte results became available as follows: sodium concentration $132 \mathrm{mmol}(\mathrm{mEq}) / 1$, potassium $8.0 \mathrm{mmol}(\mathrm{mEq}) / \mathrm{l}$, chloride $104 \mathrm{mmol}(\mathrm{mEq}) / 1$; bicarbonate $11 \mathrm{mmol}(\mathrm{mEq}) / 1$; and urea $8.5 \mathrm{mmol} / 1(51 \mathrm{mg} / 100 \mathrm{ml})$. Administration of $50 \mathrm{ml} 50 \%$ dextrose with 10 units soluble insulin and resuscitation successfully restored sinus rhythm, with normal blood pressure, and spontaneous breathing. Electrocardiography showed peak $T$ waves but no widening of the QRS complexes. The serum potassium concentration fell steadily over the next two hours to $5.0 \mathrm{mmol} / \mathrm{l}$, and apart from a focal seizure no untoward incidents occurred in the first 24 hours. 